Complutense Journal of English Studies

ISSN: 2386-3935

\title{
Translating the FAITH Frame: A Study of Two Translated Egyptian Novels
}

Ingie Zakaria $^{1}$

\begin{abstract}
This study, which is part of a larger study on the use of frame semantics in the translation of cultural elements from Arabic into English, isolates the instances where the characters from two modern Egyptian novels use language to identify themselves as members of a particular religious group, which corresponds to the frame generic $\rightarrow$ faith, and examines the manner in which these instances are translated into English. In this sense, faith is a generic frame because it dictates a particular set of behaviors, both linguistic and ideological, that is enforced by the faith community and practiced by the individuals within it. This faith community is a subset of the language community that uses a set of expressions considered typical of this community to the point where its members are recognizable through the use of these expressions. The translation issue at hand is that the TL may not offer the same possibilities to evoke a similar frame reflecting religious identity.
\end{abstract}

Keywords: semantic frames, generic frames, translating religious expressions, English translation of Arabic literature.

Contents. 1. Introduction. 1.1. Objectives. 1.2. Background. 1.2.1. Frame Semantics and Translation. 1.2.2. The Frame Typology. 1.2.3. What are generic frames? 1.2.4. Arabic and Diglossia. 2. Method. 2.1. Corpus. 2.2. Process. 2.2.1. Example Selection and Analysis. 3. Data analysis. 3.1. Expressions Used by Christian Speakers of Arabic. 3.2. Expressions Used by Muslim Speakers of Arabic. 3.3. General Expressions Derived from Religious Tradition. 4. Conclusion.

How to cite this article: Zakaria, I. (2017) Translating the Faith Frame: A Study of Two Translated Egyptian Novels, in Complutense Journal of English Studies 25, 125-142.

\section{Introduction}

\subsection{Objectives}

This study, which is part of a larger study on the utilization of frame semantics in the translation of Arabic cultural elements into English, aims at bridging the gap between linguistics and translation studies by highlighting the contribution the former may offer to explain the issues in the latter. In this case, the focus is on both translator and translation, as the mental processes involved in decoding SL (Source

1 English Department, Ain Shams University, Cairo (Egypt)

E-mail: ingie.zakaria@gmail.com 
Language) terms and encoding them in the TL (Target Language), namely categorizing knowledge and language into semantic frames, are brought to the forefront and analyzed as the motivation behind translation choices. However, the study refrains from suggesting any translation frameworks or so-called solutions to translation issues, since such suggestions rarely apply in a uniform manner to all texts and issues.

\subsection{Background}

\subsubsection{Frame Semantics and Translation}

The notion of frame semantics is based on the proposition that encoding and decoding meaning in natural languages is based on a cognitively stored scene or experience (Fillmore 1976) and that frames are conceptualizations of preprogrammed stereotypes of known items and experiences (Gawron 2011). Using frames as a vehicle for translation is, therefore, about more than translating words or even ideas; it is about translating the whole miniscule universe associated with each concept in the Source Language (SL) into one that evokes a Target Language (TL) experience that is as similar to its SL counterpart as possible, given the constraints of culture and language.

Since frame semantics is a field closely associated with Artificial Intelligence, many of the pervious works relating frame semantics to translation are more concerned with machine translation and constructing automatic cross-language semantic networks (See Sowa 1991; Pedersen 2000; Boas 2002; Dorr et al. 2002; Ploux and Ji 2003; Fung and Chen 2004, 2006; Tonelli and Pianta 2009). However, the use of frame semantics as a tool for translation extends beyond machine translation; Boas (2013) cites the FrameNet Project (Baker, Fillmore and Lowe 1998) as the main catalyst for spreading the use of frame semantics in translation in general, both manual and automated. In the context of manual translation, it provides an insight into the inner workings of the method by which the human brain identifies, interprets, and catalogues the SL as a carrier of knowledge and experience, after which it attempts to locate an equivalent in the TL that can duplicate the same process as closely as allowed by the two languages and accompanying cultures.

\subsubsection{The Frame Typology}

The frame model on which this study relies is one proposed by Rojo (2002) as an expansion of the original frame typology presented by de Vega (1984). De Vega identifies a frame typology categorized into five frame classifications: social frames, situations frames (otherwise known as scripts), domain frames, visual frames, and self-concept frames. In her elaboration of the original typology, only part of which is relevant to this study, Rojo included the self-concept frame into the more inclusive generic frame, which adds the manner in which a person views $\mathrm{him} /$ herself to the manner the community expects the person to act based on their background. 


\subsubsection{What are GENERIC Frames?}

The present study is driven by the concept of generic frames, which are frames that describe a class of objects (Jones 2015), namely the way objects or people are stereotypically expected to be, think, speak, or act based on who, what, and where they are. Jones gives an example of the generic frame archer, defining the weapon used by the archer as a bow, which then has the sub-frame longbowman, inheriting all the properties of the original generic frame archer but adding a specific type of bow to the description. An archer, represented by the frame generic $\rightarrow$ archer, is all that an archer is expected to be in terms of actions, weapons, and space. A longbowman, represented by generic $\rightarrow$ archer $\rightarrow$ longbowman is an archer who uses a slightly modified weapon. Every sub-frame, therefore, builds upon the information provided by the one before it. The original generic frames introduced by de Vega (1984) were divided into generic and self-concept frames, both of which were part of the more general social frame. The frames were combined into one category, generic frames, and used as a separate frame by Rojo (2002), which is the approach adopted in this study.

In this sense, faith is a generic frame because it dictates a particular set of behaviors, both linguistic and ideological, that is enforced by the faith community and practiced by the individuals within it. This faith community is a subset of the language community that uses a set of expressions considered typical of this community to the point where its members are recognizable through the use of these expressions.

\subsubsection{Arabic and Diglossia}

As a diglossic language, Arabic has two varieties which coexist within the same language community, each having its own distinct function (Albirini 2016). Whereas Modern Standard Arabic (MSA) is the language of the media, higher education, and intellectual and academic writing, Colloquial Arabic (QA) is the spoken variety, which is structurally and phonologically different from MSA. The differences depend on such factors as geographic location, social status, gender, idiolect, and even the social setting in which the language is spoken. The distinction must also be made between MSA and Classical Arabic (CA), the language of sacred and classical texts. Whereas MSA has distinct phonological variations depending on the country from which the speaker comes, and therefore the aforementioned religious expressions, although said in MSA, often betray where the speaker is originally from, CA is revered as the lingua franca of Islam and is expected to always be pronounced according to its original standards. This is the variety used when reciting or quoting the Quran or delivering religious sermons and lessons. While using the predominantly-written MSA in daily, nonacademic speech is usually for the purpose of sounding more educated and refined, the use of CA in everyday speech is more associated with ultra-conservative Islam than an average person trying to sound religious, or even sophisticated or intellectual.

The data has evidence of the two main varieties of Arabic found in Egypt: Modern Standard Arabic (MSA) and Egyptian Colloquial Arabic (ECA). It is noteworthy in this context that Christian-based expressions in the data do not bear the same degree of adherence to MSA or CA displayed by Muslim expressions. 
This is due to the fact that, whereas all sacred Islamic texts and classical texts related to jurisprudence were originally written in CA, Arabic Christian texts in Egypt were mostly translated into a variety of Arabic that combines MSA and ECA, thus favoring intelligibility by the average layperson over rhetorical aestheticism. This distinction contributes to the generic frame evoked by the expression and becomes one of the properties of the class identified as either Christian or Muslim.

\section{Method}

\subsection{Corpus}

Two modern Egyptian novels, Khaled Al-Khamisi's Taxi and Bahaa' Taher's Aunt Safiyya and the Monastery, were chosen as data sources for this study. They represent a variety of styles in terms of the use of Egyptian Colloquial Arabic (ECA) and Modern Standard Arabic (MSA), ranging from being almost fully written in MSA to almost fully written in ECA. Their characters also represent the two major religious communities in Egypt, Islam and Christianity. The choice to extract data from two different texts is an attempt at ensuring result objectivity rather than the outcome being one translator's modus operandi based on the style of one writer and the patterns of one text.

\subsection{Process}

\subsubsection{Example Selection and Analysis}

The main issue explored in this study is the manner in which self-identification as a follower of a certain faith is expressed through language (in this case, Arabic in its various forms) and, subsequently, the manner in which this expression is translated into English. Accordingly, the examples selected from the corpus all reflect this manner of expression. As a qualitative study, the number and frequency of expressions is not key; the focus is rather on the quality of the examples as adequate representations of generic self-identification based on faith.

The study isolates the instances where the characters from the two novels use language to identify themselves as members of a particular religious group, which corresponds to the frame generic $\rightarrow$ faith, and examines the manner in which these instances are translated into English; the frame reference evoked by the SL term is identified and compared to that of the TL term, after which the study explores the possibility of alternative TL terms which may render the SL frame reference more accurately.

Each example is cited within the context of its passage, both in Arabic script and transcribed script, the latter of which is done according to the recommendation of Bo Isaksson's Transcription of Written Arabic (cited in 5.4. Electronic sources) as seen in Encyclopedia of Arabic Language and Linguistics (vol. I, 2006). The translation of the passage as found in the published translated text is then provided and, in cases where it is necessary, an alternative translation is also suggested. 


\section{Data analysis}

Arabic, as a product of its religiously-inclined environment, uses a wide variety of faith-inspired expressions, which aids in expressing the speaker's religious identity, simultaneously connecting them to their own religious group and asserting their differences and separation from individuals belonging to other religious factions. In this sense, it is sometimes possible to deduce the religious philosophy to which a person subscribes by analyzing their Arabic speech. In ECA, the matter of distinguishing a speaker's religious affiliation, and therefore identifying the speaker's generic class as belonging under the frame Muslim or Christian, is a matter of relative simplicity when one compares how people choose to refer to the same concept or person across faith lines. For instance, whereas a Muslim would typically refer to the Virgin Mary in everyday speech as السيدة مريم' as-say-yida Maryam 'Lady

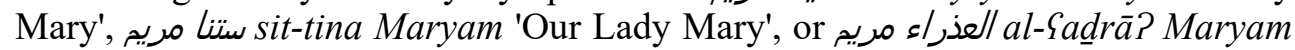
'The Virgin Mary', the latter pronounced in formal MSA tradition, a Christian speaker would refer to her, also in everyday speech, as /لعدر/ al-Sadra 'the Virgin', pronounced in informal ECA tradition.

At the level of the language as a whole, the influence of religion on the culture which has given rise to the language as we know it today is evident in rhetorical expressions based on faith but not indicating personal affiliation to faith, seamlessly integrated into everyday language usage. These expressions have lost some or all of their literal religious significance and become frozen expressions, such as

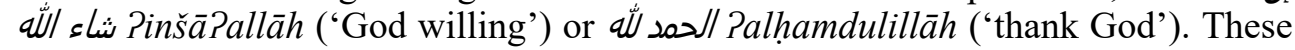
do not necessarily reflect a certain generic frame related to faith, as they do not contribute to the speech patterns of the members of a certain faith community, but rather extend over the entire speech community.

The following is an analysis of religiously-motivated speech in the two texts, categorized according to their functions, either as indicators of religious affiliation or reflections of the role played by religion in the Source Culture (SC).

\subsection{Expressions Used by Christian Speakers of Arabic}

Expressions motivated by Christianity in the data are found exclusively in Aunt Safiyya and the Monastery due to the fact that one of its central characters is a Christian monk and a significant part of the events take place in a monastery.

One of the representative expressions in the data is used to refer to a dead person, particularly a member of the clergy as المتنيح lalmitnay-yah 'the late X', which means someone who has been brought to eternal peace in Heaven or otherwise someone who has been relieved from the burdens of mortal life. The word has origins in Hebrew, as can be observed in Ruth 1:9 "The LORD grant you that ye may find rest, each of you in the house of her husband. Then she kissed them; and they lifted up their voice, and wept" where, according to the Westminster Lenin-

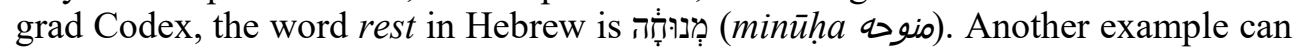
be found in Psalm 95:11 "Unto whom I swore in my wrath that they should not

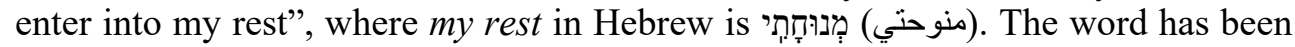
borrowed into Arabic where, according to Arabic dictionary MuSjam al-MaSāni alJami , the transitive verb ني nayyah means 'to rest' or, in cases where the subject is God, 'to call to rest in Heaven'. The word remains in use today in reference to a 
deceased member of the Christian clergy, although it is also used in prayers for the souls of non-clergy in وشية الر/قدين Päšsiyat ar-räqidīn (a modified Coptic version of the Litany for the Departed).

In Arabic, the word invariably evokes the frame generic $\rightarrow$ Christian. Even though it has been borrowed into Arabic, it has failed to remain in active usage outside the Christian community, possibly due to its Old Testament origins and its absence from any non-Christian texts. The following example from Aunt Safiyya and the Monastery is an example of the use of the word in reference to a deceased monk:

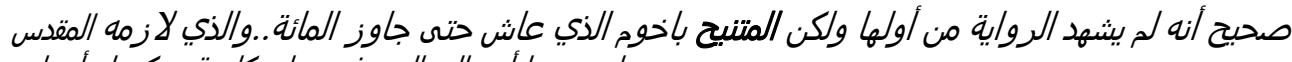
بشاي عندما أتى إلى الدير في شبابه كان قد حكى له الشياء.

šahīh Pannahū lam yašhad ar-riwāya min Pawwalihā wa-lākin al-mitnayyah Bāxūm Pal-

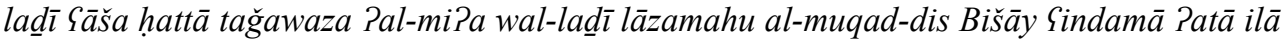
ad-dayri fì šabābihī kāna qad hakā lahū Pašyōe

To be sure, he had not witnessed the events from the beginning, but he had been told things by the late Bakhoum. This Bakhoum had lived past the age of a hundred. Bishai used to follow him around here and there, when he first came to the monastery as a novice, in his youth.

The generic frame which acts as an identity marker is lost in translation in the TT, where the word late is used. The issue in this case is the absence of a TL term that reflects the same identity marker. The TL term late is not exclusive to a specific faith or affiliation, and simply points to the frame deceased. The missing frame reference does not necessarily impact the overall frame reference Christian in reference to the deceased monk, as the identity of the monk is clear to both the Source Text (ST) and Target Text (TT) readers throughout the text with the help of contextual clues.

Another expression associated with the Christian faith and Christian practices is Paqaddis 'to go on a pilgrimage', found in Aunt Safiyya and the Monastery in a conversation between gangster Hinein, who is only Christian by birth, and the leader of his gang. The term specifically refers to the pilgrimage to the Holy Land in Palestine, Jordan, and Israel performed by Christians from all around the world. The pilgrimage was banned by the Christian Coptic Orthodox Church of Egypt in 1980 following the Camp David Treaty between Egypt and Israel. Since the events of the novel take place prior to 1980, Hinein casually (and sarcastically) refers to the Holy Pilgrimage performed by Christians to the Holy Land as God's saving grace that might redeem him after a life of crime. The term evokes the frame generic $\rightarrow$ Christian, or, more accurately, generic $\rightarrow$ devout_Christian. Unlike the previous example, this expression has a TL counterpart which transmits the same frame reference, going on a pilgrimage. To avoid confusing Muslim pilgrimage (or Hajj) and Christian pilgrimage, going on a pilgrimage to Jerusalem may be used. However, in the TT, the translator misinterprets the term and uses the TL term ordained, which evokes the frame generic $\rightarrow$ Christian_clergy. This was possibly motivated by Hinein's reference to Bishai, a monk he sarcastically claims he wants 
to emulate, and his mention of the possibility of becoming a monk himself, although the ST indicates he meant emulate Bishai's good standing with God rather than his position among the clergy:

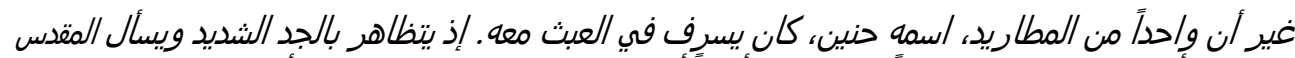

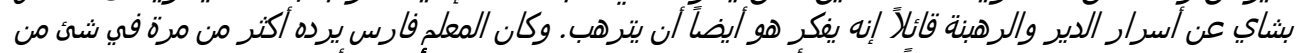
الفضب فيقول حنين متكلفاً البراءة: أنت تكره لي الخير يا معلدم بمكن أقدس وأصبح مثل هذا الرجل الطيب.

Ġayra Panna wāhidan min al-mațārīd Pismuhū hinīn kāna yusrifu fil-Sabați maShū. Pid yataz̄āharu bil-ğad-di Paš-šadīdi wa-yas?alu al-muqad-dis Biš̄ây Can Pasrār ad-dayr warrahbana qāPilan Pin-nahu yufak-kiru huwa Paydan Pan yatarahban. Wa-kāna al-muSallim Fāris yarud-duhu Pakțara min marratin fi šay?in min al-gadabi fa-yaqūlu hininn mutakallifan al-barā?a: Panta takrahu liya Pal-xayr yā muual-lim? Yumkin Puqad-dis wa-Pușbihu mițla hādāa Par-rağulu Paț-ty-yib

[...] although one of the outlaws, a Christian whose name was Hinein, would sometimes go too far in teasing him. He would look very serious and ask the miqaddis Bishai about the secrets of the monastery and monasticism, saying that he was thinking also of becoming a monk. The mi'allim Faris responded to this more than once rather irritably, but Hinein said with exaggerated innocence, "Do you begrudge me some happiness ya mi'allim? Maybe I'll be ordained, and become like this good man."

The suggested translation substitutes go on a pilgrimage to Jerusalem in order to maintain the ST frame reference generic $\rightarrow$ devout_Christian: "Maybe I'll go on a pilgrimage to Jerusalem and become like this goo $\bar{d}$ man".

The use of الرب ar-rab 'the Lord' in the ST presents a rather complicated prospect for the translator. This analysis is concerned with the SL terms الرب ar-rab and all/ al-läh 'God', and the terms God and Lord as representatives of the data and the problem it highlights.

The word rab is not exclusively Christian or Muslim per se, as it can be found in many classical non-Quran Muslim texts, notably in Al-Nasa i (2001), Ibn Taimiya's (2004), Ibn Maja (2010), and Muslim (2016). The word, however, does not occur in this form الرب ar-rab in Islamic tradition or in the everyday discourse of Muslims, but rather in the genitive form (muḍāf), as in رب الع rab al-\{ālamīn 'Lord of the Two Universes' or Lب rab-bana 'our Lord'. In the Quran, it occurs in various forms, 971 times, as opposed to aلالl al-lāh which was mentioned 2699 times (The Quranic Arabic Corpus). In various translations of the Quran, the word all/al-lāh is either translated into Allah or God, the former adopting a philosophy where الس is a proper name rather than a translatable noun, whereas رب rab 'Lord' in its different manifestations is translated into Lord. لرب ar-rab, however, is not found in Islamic tradition or Muslim discourse.

Conversely, a close examination of the occurrence of the two terms in the Arabic edition of the Bible compared to the King James Bible, reveals that الرب ar-rab occurs 5469 times in the Old Testament and 411 times in the New Testament, whereas اله occurs 1235 times in the Old Testament and 1014 times in the New Testament (St-Takla.org). While aلّ/lal-lāh invariably refers to God except for three instances where it refers to Jesus (John 1:1, John 20:28, and Isaiah 9:6), in the New 
Testament, الرب ar-rab refers to both God and Jesus, sometimes within the same verse (e.g. Matthew 22:44). In King James' Bible, the word God was mentioned 3090 times in the Old Testament and 1354 times in the New Testament, whereas Lord was mentioned 7234 times in the Old Testament and 712 times in the New Testament. In the New Testament, the word God only refers to Jesus in the same three instances as the Arabic translation, whereas Lord refers to both God and Jesus, as well as other figures of authority (Daniell 2003), the last of which is a feature it does not share with the Arabic translation. The discrepancies may be attributed to the point where the two translations depended on slightly different $\mathrm{He}$ brew and Greek manuscripts, as well as the fact that the use of Lord to indicate a non-divine figure of authority is translated into السيد as-say-yid 'the Master' in the Arabic Bible. When parallel texts were compared, the researcher observed that

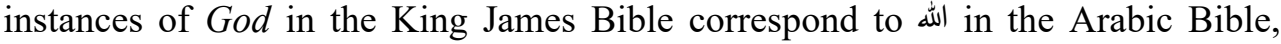
whereas Lord was translated into الرب ar-rab or السبيد as-say-yid. The frames corre-

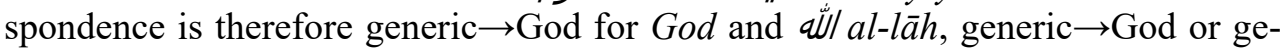
neric $\rightarrow$ Jesus for Lord and الرب ar-rab, or generic $\rightarrow$ figure_of_authority for Lord in the Biblical context. It must be noted in this context that these frame references do not apply to John 1:1, John 20:28, and Isaiah 9:6 as mentioned earlier, where God and aلl/ al-lāh indicate the frame generic $\rightarrow$ Jesus.

As far as the data is concerned, لرب lar-rab occurs twice in Aunt Safiyya and the Monastery as part of the generic $\rightarrow$ Christian frame. The use of $/$ / ar-rab in the SL, according to the aforementioned corpus statistics, is more parallel to Lord than God, but in the TL it is translated as both Lord and God in two instances throughout the text:

(1)

فيخرجهم من القدس كما أخرج الانجليز من مصر الرب بنصر جمال

Ar-rab-bu yanșuru ğamāl fayoxriğuhum min al-qudsi kamā Paxrağa l-inğilīz min miṣr

"May God grant victory to Nasser and drive them from Jerusalem, as he drove the British from Egypt."

وشاء الرب لحظتها / بأتي الر/هب جرجس ففهم، ولكنه طلب من الرجل أن يلف حول الدير وأن بأتي دون سالح ويترك رجاله جالسين أمام بوابة الدير.

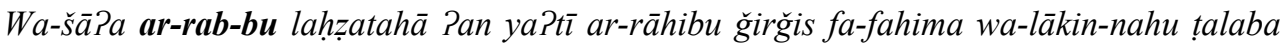
mina r-rağuli Pan yalif-fu hạwla d-dayri wa-Pan ya?tiya dūna silaḥin wa-yatruku riğalahu ğālisīna Pamāma baw-wābati d-dayr

And at that moment the Lord willed Brother Girgis to come. Brother Girgis was able to make some sense of the situation, but he asked the man to go around the monastery, to go unarmed, and to leave his men sitting in front of the monastery gate. 
It is suggested that both instances be translated into Lord in order to preserve the non-definitive ST frame reference generic $\rightarrow$ God/Jesus, instead of the definitive generic $\rightarrow$ God used in the second example:

(1)

May the Lord grant victory to Nasser and drive them from Jerusalem, as he drove the British from Egypt.

(2)

And at that moment the Lord willed Brother Girgis to come. Brother Girgis was able to make some sense of the situation, but he asked the man to go around the monastery, to go unarmed, and to leave his men sitting in front of the monastery gate.

\subsection{Expressions Used by Muslim Speakers of Arabic}

Arabic expressions based on Islam are derived from Quran and Hadith, as well as expressions commonly used in Islamic jurisprudence, and are usually said in MSA in an everyday colloquial conversation to distinguish them from their more common, less formal ECA cousins. In the SL, using such expressions usually confirms the speaker's identity as a Muslim, and reflects his or her status as a religious person. Where translation is concerned, the TL presents a problem where Muslims sometimes identify themselves by using MSA and CA loan words in their nonArabic speech in matters pertaining to their faith, or even in everyday speech when injecting expressions such as Inshallah 'God willing' or Alhamdulillah 'thank God' into their conversations in order to preserve their meaning without distortion. This reinforces the view held by many Muslims that Arabic, namely CA and MSA, is the official language of Islam, which more often than not attaches undue sanctity to the language itself due to the belief that it is the language in which God transmitted his message to his Prophet (Peters 2003). Within a predominantly non Arabic-speaking community, this sentiment makes learning Arabic a holy quest for Muslims and creates a niche where self-identification using MSA and CA loan words creates a sense of camaraderie and possibly serves as a tool of exclusion, since it is unintelligible to non-Muslims and many of the second- and thirdgeneration Muslims who were born into an English-speaking community (Mujahid 2006). The much-ridiculed term Islamic English (Faruqi 1986), which refers to the use of MSA and CA loan words in non-Arabic speech produced by Muslims living in non Arabic-speaking communities, was even coined to refer to the phenomenon, although it has been criticized and satirized for its absurdity (Bilici 2012 and Leonard 2003). The use of so-called Islamic English or, more recently, Muslim English, successfully and fully transmits the frame generic $\rightarrow$ Muslim and functions as a tool of identity assertion. Its use, however, is more common with single words or shorter expressions, such as Zakat 'alms', Salah 'prayer', Janna 'heaven', Inshallah 'God willing', or Alhamdulillah 'thank God'. Longer expressions, on the other hand, are more problematic because of their complexity. As can be observed in the data, translating them into English, while it may transmit the core frame generic $\rightarrow$ religious, does not necessarily do the same for generic $\rightarrow$ muslim (or generic $\rightarrow$ devout_Muslim, depending on context), because the reference is fully dependent on the expression being used in CA or MSA. This leaves this portion of the 
interpretation for the context. These observations raise the question of whether the problem is due to the use of "Islamic English" in the first place, in that using the expected non-Arabic translations of the Arabic terms might have normalized these terms in the new language, making the language more seamless and inclusive instead of borrowing Arabic words into another language and only having members of the Muslim faith community fully understand the conversation. The current state of affairs has imposed a transliteration reflecting the original generic $\rightarrow$ Muslim frame, as well as a functional translation reflecting the sub-frame gener$\mathrm{ic} \rightarrow$ religious. In a world where Islamic English does not exist, the norm would be a universal generic $\rightarrow$ religious frame, motivated solely by the mention of general references to God, except for expressions evoking concepts specifically tied to Islam, such as Prophet Mohammed.

One such expression can be found in Aunt Safiyya and the Monastery, when the narrator's father, the preacher at the local mosque, refers to Prophet Mohammed as Pal-habīb Pal-muștafāa, a commonly used epithet that literally means 'the loved one, the chosen one'. The epithet was not directly derived from a specific religious text, but has come to reflect the veneration and love devout Muslims have for Prophet Mohammed. The use of the term automatically identifies the speaker as a devout Muslim and poses a problem in the translation of the text into a language where no similar expression exists:

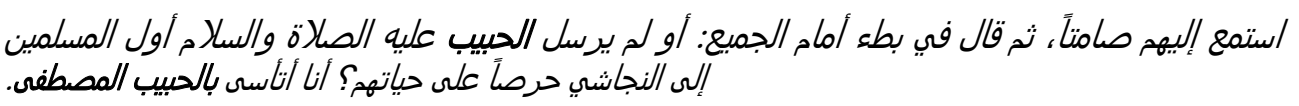

PistamaSa lahum șāmitan țum-ma qāla fì buțin Pamāma Pal-amī̧: Pawa lam yursilu Palhabību Salay-hi Paș-șlātu was-salāmu Paw-wala Pal-muslimina Pilā Pan-nağāšiy-yi hirșan Galā hayātihim? Panā PataPas-sā bil-habībi Pal-muștafā

My father listened to them in silence. Then he spoke slowly, in the presence of the whole crowd, saying, "Did not our Beloved Prophet, blessings and peace be upon him, send the first Muslims to el-Nigashi, in defense of their lives? I take solace in the Beloved, the Chosen One."

In the TT, referring to a person as the beloved, the chosen one would not decode any frame in the mind of the TL reader unless he or she held the same understanding of the Muslim faith as the ST speaker and was familiar with the terms used to describe certain concepts within the framework of Islam. The first reference to الحبيب al-habìb 'the Beloved' in the passage may as well be interpreted as soعليه الصالة Salay-hi aṣ-șalätu was-saläm 'peace be upon him' which clearly points the ST reader to generic $\rightarrow$ prophet_of_Islam. A TT reader of a different or nonexistent religious affiliation may fail to recognize the reference, which explains the use of our Beloved Prophet to provide further background. The addition of Prophet also provides context and points the TT reader to the frame generic $\rightarrow$ Prophet_of_Islam for the Beloved, the Chosen One later in the same passage, which would have left a gap in the flow of information in the TT if its reference to Prophet Mohammed had not been explained. 
Another example of an expression motivated by the Quran is also found in Aunt Safiyya and the Monastery, used by the narrator's father. The expression hasbiya al-lāhu wa-niSma al-wakīl 'God is my only solace/God will take care of everything' is common in conversational Arabic, usually used when the speaker is in a position of weakness or has been treated unjustly, and literally means God is enough for me and He is the best support. It is taken from the Quran in a slightly different form حسبنا الله ونعم الوكيل hasbu-na al-lāhu wa-niSma al-wakīl (3:173) in reference to those who hold on to their faith in the face of adversity and animosity. The expression is therefore directly associated with generic $\rightarrow$ Muslim, although the sub-frame devout is not necessarily attached to the reference:

ولكن أبي لوح بيده وقال: فعلت ما برضي ربي. وحسبي الله ونعم الوكيل.

Wa-lakin-na Pabì law-waḥa bi-yadihi wa-qāl: faSaltu mā yurḍiya rab-bī wa-ḥasbiya allāhu wa-niSma al-wakīl

But my father waved his hand, saying, "I've done as my Lord would have me do, and that's good enough. Leave the rest to God.”

The TT in this case provides a feasible functional translation, with the mention of God evoking the frame generic $\rightarrow$ religious, but not necessarily generic $\rightarrow$ Muslim. Transliterating the term would be futile due to its length and complexity, and would not add anything to the TT reader's experience. This is a case where context may be left to cover the remaining aspects of the frame reference, identifying the speaker as a Muslim by the prior mention of his function as the preacher at the local mosque.

A similar issue can be found in Taxi, also in reference to God. In Islamic tradition God has one-hundred names by which he may be called, usually used individually or in pairs as used in the Quran. Common examples are arrahmān ar-rahìm 'the all-merciful' and السمبع المجبيب as-samīs al-mujīb 'the one who listens and answers', the latter of which can be found in the example below:

$$
\text { كان الاثنان في صاة..كل بناجي الآخر، وكالهما وجها وجهيهما للسماء عسى أن تفتح طاقة فيها وتصمل توسالهما }
$$

Kāna al-ịnnān fì šalātin kul-lun yunāği al-āxara wa-kilāhumā wağ-ğahā wağhayhumā lis-

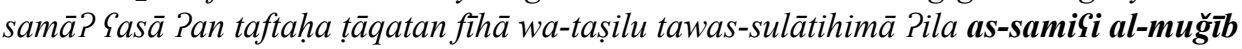

The two were praying, each whispering to the other, both turning their faces to the heavens on the chance that a portal would open there and their prayers would reach the One who Listens and Answers.

Handled in the same manner as the TT in Aunt Safiyya and the Monastery, the expression is translated functionally, providing an accurate interpretation of the meanings of the two names used in the ST, the One who Listens and Answers, and capitalizing the first letter of each word to transmit the sub-frame generic $\rightarrow$ proper_name, motivated by the capitalization of all nouns and pronouns asso- 
ciated with God in Latin-script Islamic tradition as a method of indicating sanctity and divinity. Similar to the previous example, the translation does not directly evoke generic $\rightarrow$ Muslim except to TL readers familiar with English expressions motivated by Islam. Without the help of the context, it would not even evoke the frame generic $\rightarrow$ God, but rather a more general generic $\rightarrow$ deity or generic $\rightarrow$ higher_power. Contextual information indicates that the events take place in Egypt and that the SL is Arabic, which some (but not all) TL readers may identify as a language containing numerous expressions motivated by monotheistic religions. The One who Listens and Answers, therefore, could refer to any lowercase god if it weren't for context.

The term تبرج tabar-ruğ 'adornment' is another word associated with Islamic discourse. According to ArabiCorpus, the Arabic language corpus compiled and tagged at Brigham Young University, the word is exclusively found in the Quran and, more commonly, discourse admonishing women for lack of modesty. The word carries a largely negative frame reference visual $\rightarrow$ immodest (and, some might say, an implied visual $\rightarrow$ slutty and/or generic $\rightarrow$ immoral), except for cases where the discourse is more geared towards encouraging women to show such immodesty around their husbands, in which case the frame transforms itself into visual $\rightarrow$ permissibly_appealing and visual $\rightarrow$ permissibly_seductive, the sub-frame permissibly here being a key component in the frame reference due to its background in religious discourse where a woman is expected to look appealing for her husband. The term was only mentioned in the Quran itself twice (33:33, otherwise known as the Verse of Purification) in the context of forbidding the immodest attire associated with pre-Islamic times, which is the source of later usage in Islamic discourse. The different translations of the word in various translations of the Quran and the subsequent texts of Islamic discourse is problematic; whereas sometimes it is translated into 'display', some other times it is translated into 'adorn'. The former indicates the inadvisability of displaying a woman's body to the outside world, whereas the latter implies that any form of adornment is forbidden, which takes the term across a variety of meanings, ranging from the general frame generic $\rightarrow$ modest to the more restrictive frame generic $\rightarrow$ plain or generic $\rightarrow$ unadorned, the latter of which is commonly associated with a more austere, puritanical Islamic doctrine and patriarchal religious discourse.

In the following example from Taxi, the ultra-conservative form of Islam adopted by the speaker, one of the taxi drivers encountered by the narrator, is clear throughout the dialogue. The use of the word تبرج tabar-rug itself is associated with the same brand of semi-radical discourse, evoking both generic $\rightarrow$ Muslim and generic $\rightarrow$ ultra_conservative of the speaker, as well as the aforementioned visual $\rightarrow$ immodest and its associated implications. The use of adornment rather than display in the translation seems fitting in this context, evoking the same image of the religious zealot in the TL as its SL counterpart does in the ST:

\section{التبرج اليوم اصبح عري ،البنت تلبس فازلة وبنطلون وكأنها لا تلبس شئ}

At-tabar-rŭ̆ al-yawm aṣbaḥ̄a Guriy. Al-bint talbis fanil-la wa-banțalūn wa-kaPan-nahā lā talbasu šay? 
Today adornment means nakedness. Girls are wearing T-shirts and trousers as though they were wearing nothing.

As mentioned in 2. RELIGIOUS JARGON, colloquial expressions evoking the name of God can be divided into two categories: expressions directly indicating the speaker's faith and others used across all creeds. The latter, represented by expressions like aلّ الحمد al-hamdulil-lāh 'thank God' may be considered frozen expressions which have lost their specific religious significance, derived from the use of aلالlal-lāh 'God', and become automatic responses to everyday queries. The former is represented in the following example from Taxi:

$$
\text { السائق:ماعرفش /يه اللي حصل بعد كده الدنيا اللي /تغيرت ولا أنا اللي /تغيرت ..تصدق بالله }
$$

أنا :لا إله إلا الله .

السائق :أنا أول مرة أتكلم في الموضوع ده ..وماكتنش واخد بالي انيي بقالي حوالي حاجة وعشرين سنة مشفتش فيلم .

As-sāPiq: maSraf̌s Peh Pil-li hașal baSd kida id-dinya Pil-li itgay-yarit wal-la Pana Pil-li itgay-yart..tisad-da? bil-lāh?

\section{Pana: lā Pilāha Pil-la al-lāh}

As-sāPiq: Pana Paw-wil mar-ra atkal-lim f-il-mawḍ̄ $\bar{\varphi}$ dah wi-makuntiš wāxid bāli Pin-ni baPali ḥawāli haga wi-Sišrīn sana mašuftiš film

I don't know what happened. The world changed, or it was me that changed...Want to hear something amazing?

\section{Sure, go ahead.}

This is the first time I've spoken about this. I hadn't realised that I haven't seen a film in about twenty-something years.

The idiomatic expressions تصدق بالله tisad-da? bil-lāh 'do you believe in God?' and its response للَ إله llä Pilāha il-la al-lāh 'there is no God but the one God' are not intended for their literal meaning, which is inquiring about the addressee's religious belief, but rather to convey the frame used by the translator in the TT, which is topic introduction. The idiomatic use of the expression in the SL, however, has an additional, equally relevant frame of asserting the interlocutors' religious identity as Muslims, so the expression, in addition to its function, has the subfunction of identity assertion and, therefore, evokes the additional frame generic $\rightarrow$ Muslim. It is, in other words, an idiom used exclusively by Muslim speakers of Arabic. The expression combines features from the two categories mentioned above in that it lacks a direct religious meaning linked to God while simultaneously identifying the interlocutors as being Muslim due to the use of the exclusively Muslim proclamation of لإله إله la la Pilāha il-la al-lāh. The functional translation 
in the TT conveys the idiom frame topic introduction adequately, but fails to do the same for the generic frame, which is an expected consequence of translating idiomatic expressions, where one or more frame references are lost in translation due to the multiple layers of reference. The issue here is a matter of setting frame priorities and deciding on the frame reference more relevant to the context and thus more worthy of transmission. In this case, it was the translator's choice to go the functional path and dispense of the more secondary generic frame, which does not add relevant information to the TT.

\subsection{General Expressions Derived From Religious Tradition}

This part of the study examines expressions motivated by faith in general, without indicating the specific religious affiliation of the speaker, but rather pointing to a general generic $\rightarrow$ faith frame, whose sub-frame depends on the term at hand.

The concept of حرarām 'forbidden' is one that is omnipresent in Arabic religious discourse. The term originally means a sinful or prohibited act, or a sacred place or object. In ECA and some less formal MSA texts, it has also acquired the meaning 'unfair' or 'unspeakable'. This is a case where the distinction between the two polysemes is necessary in order to verify which frame is being referenced. The first frame, indicating sinful or prohibited behavior, would point the reader/translator in the direction of religious (for the interlocutor) and sinful_act (for the behavior). Alternately, the less formal frame would reference unjust (or outrageous) both for the agent of the act and for the act itself. Misinterpretation could result in a false religious sub-frame and different interpretation of the TT than was intended in the ST, which is a common problem of polysemy in translation. Interpreting the term involves knowledge of both the culture and the underlying religious beliefs to be able to discern what the interlocutors would classify as outright sinful and what they would otherwise identify as unsavory behavior without the religiously-motivated outrage.

In Aunt Safiyya and the Monastery, the context of the term حرaram is a visit made by the narrator's mother following his father's altercation with the young widow over naming her manure donkey after her husband's killer. The context does not reveal any religiously objectionable behavior and no overtly sinful actions, which is why the TL term unspeakable is sufficient in this context:

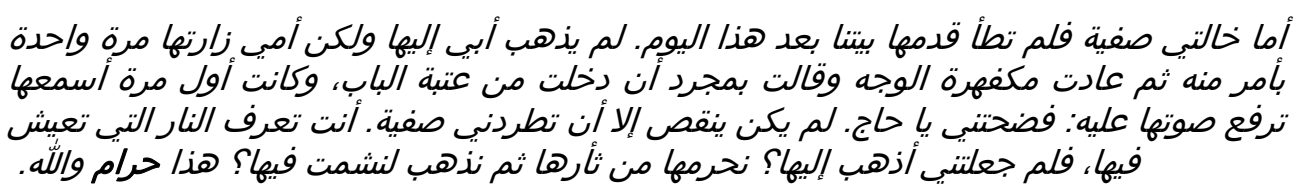

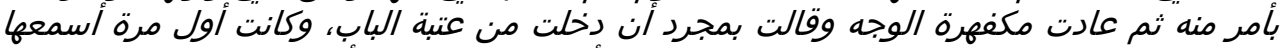

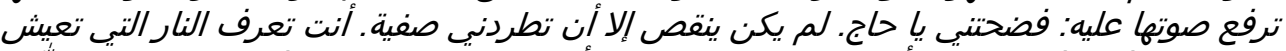
فيها، فلم جعلتيى أذهب إليها؟ نحرمها من ثأرها ثم نذهب لنشي لنشمت فيها؟ هذا حرام والله.

Pam-mā xālati šafiy-ya fa-lam tața? qadamuhā baytanā baSda hăda al-yawm. Lam yadhabu Pabī Pilayhā wa-lākin-na Pum-mi zarat-hā mar-ratan wahidatan bi-Pamrin minhu tum-ma Sadat mukfahir-rat al-wağhi wa-qālat bi-muğar-radi Pan daxalat men Satabati lbāb wa-kānat Paw-wala mar-ratin Pasma\}uhā tarfa\}u șawtahā Sahayhi: fadahtan̄̄ yā hāăg. Lam yakun yanquṣu Pil-lā Pan tatrudunī šafiy-ya. Panta taSrifu n-nāra al-latī taSīš fïhā fa-

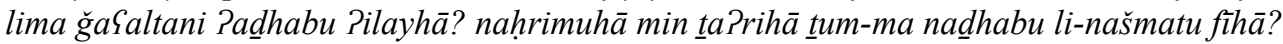
hādā harämun wal-lāh 
As for Aunt Safiyya, she did not set foot in our house after that day. My father didn't go to see her, but my mother visited her one time because he asked her to, and she returned grim faced. She announced the moment she walked in the door-and this was the first time 1 ever heard her raise her voice to my father- "You've disgraced me, ya hagg! No less than drive me away, that's what she did! You know the hell Safiyya is living, so why did you make me go to her? We deprive her of her revenge, then we go and rub her face in it? My God, this is unspeakable!"

Later in the text, however, the concept of religiously-prohibited acts surface when Safiyya's bodyguards refuse to assassinate her husband's killer, Harbi, inside the monastery, objecting that it would be حرام harām, or an act of sin. The word sin is used in the TT to underline the interlocutors' ideology regarding the situation and the sanctity of the monastery, both حرaräm and sin referencing religious for the interlocutor (though without subtle sarcasm at the selectively religious outlaws who refuse to commit murder inside a holy place) and sin for the act itself:

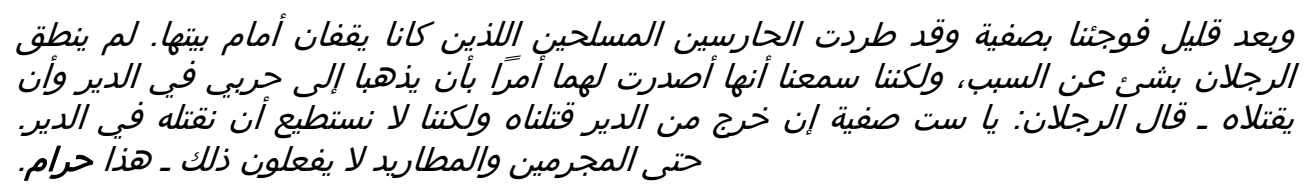

Wa-baSda qal̄̄l füğiPnā bi-šafiy-ya wa-qad țaradat al-ḥ̄risayn al-musal-lahayn al-ladayn kānāyaqifān Pamāma baytihāa. lam yanțiq ar-rağulān bi-šayPin Can as-sababi wa-lākinnana samiSnā Pan-nahā Pașdarat lahumā Pamran bi Pan yadhabā Pilā harbī fi d-dayr waPan yaqtulāh - qāla r-rağulān: yā sit šafiy-ya Pin xarağa min ad-dayri qatalnāhu wa-lākinnana lā nastațīiu Pan naqtuluhu fi d-dayr. hat-tā l-muğrimīna wal-mațarīda lā yaf̧alūna dialik - hā $\underline{d} \bar{a}$ harāàm.

A short time later, we were startled to learn that Safiyya had driven off the two armed guards who had stood in front of her house. The two men didn't explain the reason, but we heard that she had ordered them to go to Harbi at the monastery and kill him. The men said, "Madame Safiyya, if he comes out of the monastery, we'll kill him, but we can't kill him within the monastery grounds. Even criminals and outlaws don't do that-it's a sin!"

The same concept is also seen in Taxi, where the driver mentions that the only reason more people are not committing suicide is because it is حرام harām or, in this context, prohibited, both indicating the frame religious for the speaker and sin for the act:

السائق: مش للدرجة دي، هئ هئ، إنت عارف لو الاتتحار مش حرام، كل اللي عارفهم كان زمانهم As-saPiq: mish lid-daraga di hi? hi?. Pinta Yārif law al-intiḥ̄ar mish harām kul il-lī Sarifhum kān zamanhum intaharu min zamān.

Not to that extent? Haha. You know, if suicide wasn't prohibited, everyone I know would have committed suicide ages ago. 
None of these expressions indicate a specific religion practiced by the interlocutor, but they do indicate the general tendency toward injecting religion or actions related to it in everyday conversation. Maintaining these references, where possible, give the TL reader a flavor of the cultural background of the ST.

\section{Conclusions}

Generic frames reflect both external and internal cognitive representations of what the individuals, as well as the culture from which the individual hails, considers normal and expected. Faith and religious beliefs are one aspect of what cultures may consider generic, normal, and expected. The different functions of faithmotivated expressions, whether they indicate the speakers' religious beliefs or merely act as a frozen expression based on the culture's propensity towards religious traditions are among the important aspects of texts that translators need to acknowledge. Given the colossal difference in what individuals and cultures consider generic, the translator's mission must be to focus on transmitting the idea of what is generic in the SL, and therefore the SC, which may include a significant amount of explanation in the body of the TT.

The utilization of semantic frames in the process of translating religiouslymotivated expressions provides a framework through which the translator may separate the different layers of meaning intended by the SL and attempt to duplicate them in the TL, with the chance to prioritize layers in cases where not the entire frame package is transferable into the TL. The idea to use frame semantics as a vehicle for translation is one based on the ability to catalogue and analyze knowledge, and appreciate the various levels of information that may be offered by a single concept.

\section{References}

\section{Primary Arabic Sources}

Alkhamissi, K. (2011). Taxi. Cairo: Dār ash-shurūq.

Taher, B. (1996). Xaltī șafiy-ya wad-dīr. Cairo: Dār al-Hilāl .

\section{Primary English Sources}

Alkhamissi, K. (2011). Taxi. Transl. J. Wright. Doha: Bloomsbury Qatar Foundation Publishing.

Taher, B. (1996). Aunt Safiyya and the Monastery. Transl. B. Romaine. Berkeley: University of California Press.

\section{Secondary Sources}

Al-Pimām Muslim (2016). šah̄̄h Muslim bi-šarḥi an-nawawiy. Beirut: Dar ul-Ma9rifa. Albirini, A. (2016). Modern Arabic Sociolinguistics: Diglossia, variation, code switching, attitudes and identity. London: Routledge. 
An-NisāPiy, A. (2001). As-Sunan al-Kubrā lin-Nisāeiy. Beirut: MuPas-sat ar-Risāla.

Al-Qizwīniy, A. (1953). Sunan ibn Māja. Cairo: Dār Piḥyā? al-kutub al-Yarabiy-ya.

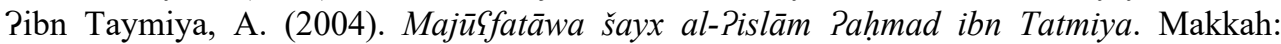
Mujam-maৎ al-malik Fahad li-ṭibāৎat al-muṣḥaf aš-šarīf.

Baker, C., C. Fillmore \& J. Lowe (1998). The Berkeley FrameNet Project. Proceedings of the 17th international conference on Computational Linguistics. Volume 1.

Bilici, M. (2012). Finding Mecca in America: How Islam is Becoming an American Religion. Chicago: The University of Chicago Press.

Boas, H. (2002). Bilingual Framenet dictionaries for machine translation. Proceedings of the Third International Conference on Language Resources and Evaluation (LREC 2002, Las Palmas, Spain), Vol. IV, 1364-1371.

Boas, H. (2013). "Frame Semantics and translation." In A. Rojo and I. IbarretxteAntunano, eds., 125-158.

Daniell, D. (2003). The Bible in English: Its History and Influence. Yale University Press.

Dorr, B. J., G. Levow \& D. Lin (2002). Construction of a Chinese-English verb lexicon for machine translation. Machine Translation, Special Issue on Embedded MT 17:1-2.

Faruqi, I. (1986). Towards Islamic English. Ann Arbor: New Era Publications

Fillmore, C. J. (1976). Frame semantics and the nature of language, Annals of the New York Academy of Sciences: Conference on the Origin and Development of Language and Speech. Vol. 280: 20-32.

Fung, P. \& B. Chen (2004). BiFrameNet: Bilingual frame semantics resources construction by cross-lingual induction. Proceedings of COLING 2004, 931-935.

Fung, P. \& B. Chen (2006). Robust Word Sense Translation by EM Learning of Frame Semantics. Proceedings of the COLING/ACL 2006 Main Conference Poster Sessions in Sydney, 239-246.

Gawron, J. M. (2011). Frame semantics. In K. von Heusinger, C. Maienborn and P. Portner, eds., 664-687.

Jones, M. T. (2015). Artificial Intelligence: A Systems Approach. Sudbury. Massachusetts: Johns and Bartlett Publishers.

Leonard, K. I. (2003). Muslims in the United States: The State of Research. New York: Russell Sage Foundation.

Nicolas, N and R. Mitkov, eds. (2000). Recent Advances in Natural Language Processing II. Amsterdam: John Benjamins.

Mujahid, A. (2006). Can There Be Muslim English? Retrieved from $<$ http://www.soundvision.com/article/can-there-be-muslim-english> (Accessed November 18 2017).

Pedersen, B. S. (2000) Lexical ambiguity in machine translation: Using frame semantics for expressing regularities in polysemy. In N. Nicolas and R. Mitkov, eds., s.p.

Ploux, S. and H. Ji (2003). A model for matching semantic maps between languages (French/English, English/French). Computational Linguistics 29.2: 155-178.

Rojo, A. M. (2002). Applying frame semantics to translation: A practical example. Meta: Translators' Journal 4.3: 312-50.

Rojo, A. and I. Ibarretxte-Antuñano, eds. (2013). Cognitive Linguistics and Translation. Berlin and New York: Mouton de Gruyter.

Sowa, F. (1991). Principles of Semantic Networks. San Mateo: Morgan Kaufman.

Tonelli, S. \& E. Pianta (2009). Three issues in cross-language frame information transfer. Proceedings of the RANLP 2009, Borovets, Bulgaria, September 2009. Unpublished conference paper. 
Versteegh, K., M. Eid, A. Elgibali, M. Woidich and A. Zaborski (2006). Encyclopedia of Arabic language and linguistics. Vol. I. Leiden/Boston: Brill.

Von Heusinger, K., C. Maienborn and P. Portner, eds. (2011). Semantics: an international handbook of natural language meaning. Berlin: de Gruyter Mouton.

\section{Electronic Sources}

ArabiCorpus at Brigham Young University. <http://arabicorpus.byu.edu> (Accessed November 18 2017).

Corpus of Contemporary American English (COCA). $<$ http://www.americancorpus.org $>$ (Accessed November 18 2017).

International Cooperative Alliance. <http://ica.coop> (Accessed November 18 2017). > (Accessed November 18 2017).

Isaksson, Bo, Transcription of written Arabic. Uppsala University. Accessible through $<$ http://www.lingfil.uu.se/digitalAssets/94/94977_transcription-ofarabicEN.pdf $>$ (Accessed November 18 2017).

St. Takla. <http://st-takla.org > (Accessed November 18 2017).

The Quranic Arabic Corpus. <http://corpus.quran.com> (Accessed November 18 2017).

The Westminster Leningrad Codex. <http://tanach.us> (Accessed November 18 2017).

The World English Bible Corpus. <https://corpling.uis.georgetown.edu> (Accessed November 18 2017). 